JAMP: Jurnal Adminitrasi dan Manajemen Pendidikan Volume 1 Nomor 3 September 2018, Hal : 358-363

Tersedia Online di http://journal2.um.ac.id/index.php/jamp/ ISSN 2615-8574 (online)

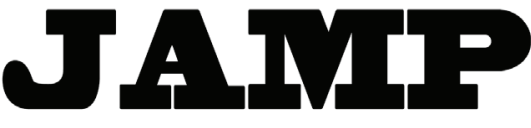

JURNAL ADMINISTRASI DAN MANAJEMEN PENDIDIKAN

\title{
KEPEMIMPINAN PERUBAHAN KEPALA SEKOLAH DALAM PENINGKATAN MUTU PENDIDIKAN
}

\author{
Anna Mar'atuz Zahro \\ Ahmad Yusuf Sobri \\ Ahmad Nurabadi
}

\author{
annamaratuz@gmail.com \\ Universitas Negeri Malang, Jl. Semarang No. 5 Malang 65145
}

\begin{abstract}
The purpose of this research to know about (1) the role of headmaster as a leadership of change, (2) the principal's strategy as a leadership of change, (3) innovation principal as a leadership of change, (4) factors supporting of change, and (5) inhibiting factors of change. This research uses a qualitative approach with case study design. Presearch location at SMA Nasional Malang. Data collection techniques with interviews, observation, and documentation. The results of this research (1) the role of headmaster as a leadership of change, the first role as visionary, responsible, locomotive, motivator, and partner work, (2) the strategy used by the principal is by improving the management of students and the management of teaching and education personnel, fostering a school culture, supervising learning, and preparing outputs thoroughly, (3) innovations made by the principal of gopek management and athlete classes, (4) the factors that support the change come from the internal school such as the principal's leadership, the support of the foundation and the means of infrastructure, from the external needs of the community for education and competition between schools, and (5) the inhibiting factors of change come from the difficult teacher's mindset, teacher competence, and poor school image in society.
\end{abstract}

Keywords: changes leadership, education quality improvment

\begin{abstract}
Abstrak: Penelitian ini bertujuan untuk mengetahui (1) peran kepala sekolah sebagai pemimpin perubahan, (2) strategi kepala sekolah sebagai pemimpin perubahan, (3) inovasi kepala sekolah sebagai pemimpin perubahan, (4) faktor pendukung perubahan, dan (5) faktor penghambat perubahan. Penelitian ini menggunakan pendekatan kualitatif, dengan rancangan penelitian studi kasus. Lokasi penelitian ini di SMA Nasional Malang. Teknik pengumpulan data melalui wawancara secara mendalam, observasi lapangan serta dokumentasi. Hasil dari penelitian ini (1) peran kepala sekolah sebagai pemimpin perubahan yaitu pertama berperan sebagai pemimpin yang visioner, penanggung jawab, lokomotif, motivator, dan patner kerja, (2) strategi yang digunakan kepala sekolah yaitu dengan memperbaiki manajemen peserta didik dan manajemen tenaga pendidik dan kependidikan, menumbuhkan budaya sekolah, melakukan supervisi pembelajaran, dan mempersiapkan output secara matang, (3) inovasi yang dibuat oleh kepala sekolah yaitu program manajemen gopek dan kelas atlet, (4) faktor pendukung perubahan berasal dari internal sekolah seperti kepemimpinan kepala sekolah, dukungan yayasan dan sarana prasarana, dari eksternal yaitu kebutuhan masyarakat akan pendidikan dan persaingan antar sekolah, (5) faktor penghambat perubahan berasal dari mindset guru sulit diubah, kompetensi guru, dan image sekolah kurang baik di masyarakat.
\end{abstract}

Kata kunci: kepemimpinan perubahan, mutu pendidikan 
Perubahan zaman yang semakin cepat mengakibatkan berubahnya semua aspek kehidupan termasuk pendidikan. Sekolah sebagai salah satu lembaga pendidikan formal bagi masyarakat harus selalu melakukan perubahan untuk peningkatan mutu pendidikan. Mutohar (2013:124) menyatakan "peningkatan mutu sekolah pada hakikatnya adalah suatu strategi untuk memperbaiki mutu pendidikan dengan jalan pemberian kewenangan dan tanggungjawab pengambilan keputusan kepada kepala sekolah dengan melibatkan partisipasi individual, baik personel sekolah maupun anggota masyarakat". Peningkatan mutu merupakan kerja keras yang harus mendapatkan dukungan dari semua semua warga sekolah. Mutu suatu sekolah tidak hanya dilihat dari seberapa banyak sekolah terebut mendapatkan prestasi. Menurut Sobri (2016) kualitas sekolah tidak serta merta hanya dilihat dari lulusan yang dihasilkan dan dapat melanjutkan pada jenjang dan jenis pendidikan tertentu. Namun kualitas sekolah juga ditentukan oleh faktor-faktor lainnya, yaitu bagaimana proses belajar mengajar yang dijalankan di sekolah, bagaimana pengelolaan pendidikan dalam melakukan pelayanan terhadap konsumen pendidikan dan beberapa faktor lain yang perlu dipertimbangkan.

Sekolah yang memenangkan persaingan di masa mendatang adalah sekolah yang mampu dengan cepat merespon terhadap perubahan. Sekolah diharapkan mampu membuat perubahan yang didesain agar lebih responsif pada lingkungan. Artinya perubahan perlu dilakukan oleh suatu sekolah sesuai dengan kebutuhan lingkungan sehingga tidak ditinggalkan oleh masyarakat. Untuk itu peran pemimpin sangat diperlukan suatu organisasi khususnya perannya dalam membantu proses perubahan. Selain perannya yang dibutuhkan dalam proses perubahan, kepala sekolah juga harus memiliki strategi yang matang agar perubahan tersebut benar-benar terwujud dengan lahirnya inovasi-inovasi baru yang berdampak pada peningkatan mutu pendidikan di sekolah.

Menurut Wibowo (2012:1) "perubahan adalah transformasi dari keadaan sekarang menuju keadaan yang diharapkan di masa yang akan datang, suatu keadaan yang lebih baik. Perubahan merupakan suatu wujud nyata dari kehidupan yang mampu mendorong atau memotivasi sesorang untuk mengubah sesuatu menjadi berbeda dari sebelumnya melalui sebuah proses yang dapat terjadi di mana saja dan kapan saja". Perubahan tersebut dapat dikekola oleh pemimpin melalui kepemimpinannya. Wibowo (2012) menyebutkan beberapa peran pemimpin dalam membawa perubahan kepada organisasinya meliputi; (a) menciptakan hubungan kerja efektif; (b) pergeseran fungsi manajer; (c) memimpin dengan contoh; (d) mempengaruhi orang lain; (e) megembangkan team work; (f) melibatkan bawahan dalam pengambilan keputusan; (g) menjadikan pemberdayaan kepada bawahan sebagai way of life; dan (h) membangun komitmen. Selain perannya yang besar dalam membawa perubahan, seorang pemimpin juga harus mempunyai strategi yang matang untuk mewujudkan perubahan tersebut menjadi nyata.

Ketidakmampuan pemimpin dalam menyusun strategi perubahan dapat berakibat pada kegagalan. Menurut Wibowo (2012) ada beberapa strategi yang dapat digunakan oleh pemimpin perubahan antara lain; (a) melakukan akselerasi (percepatan) perubahan di masa depan; (b) pemimpin harus menjadi sentral (pusaran/motor) perubahan; (c) memiliki langkah-langkah yang jelas dalam memipin perubahan; (d) menyeimbangkan antara perubahan dan kontinuitas; dan (e) meningkatkan kepuasan pekerja. Melalui peran dan strategi yang digunakan oleh pemimpin, maka akan tercipta sebuah inovasiinovasi yang berdampak pada peningkatan mutu pendidikan. Suharsaputra (2016:303), menjelaskan "inovasi pendidikan melingkupi segala sesuatu kebaruan yang mampu membawa lembaga pendidikan menjadi lebih bermutu dalam menyelenggarakan proses pendidikan atau pembelajaran dalam rangka meningkatkan mutu pendidikan, yang tercermin dari output lulusan yang berprestasi, maupun outcome yang bermanfaat bagi masyarakat.

Namun demikian, untuk membawa perubahan yang besar terdapat beberapa kendala yang menghambat pemimpin. Kaufman (1985) mengatakan bahwa kegagalan suatu organisasi dalam melakukan perubahan dapat disebabkan oleh beberapa faktor yaitu (1) hasrat untuk mempertahankan kestabilan hidup bersama, (2) pertimbangan atas lawan-lawan yang mungkin dihadapi untuk mengadakan perubahan, dan (3) ketidakmampuan untuk mengadakan perubahan. Sedangkan Robbins (2006) menyebutkan beberapa sumber-sumber penolakan yang bersifat individual yaitu (1) kebiasaan, ada sebagian individu menolak perubahan karena sudah terbiasa dengan "gaya lama" yang ia jalankan, (2) keamanan, orang dengan kebutuhan yang tinggi akan keamanan cenderung menolak perubahan karena 
akan mengancam perasaan aman mereka, dan (3) faktor-faktor ekonomi, sumber penolakan ini adalah kekhawatiran bahwa perubahan itu akan mengurangi penghasilan seseorang. Hambatan-hambatan tersebut pasti akan ditemui oleh pemimpin organisasi dalam melakukan perubahan. Untuk itu pemimpin harus mampu mengantisipasi dan mengatasi hambatan tersebut agar perubahan yang dilakukan dapat berhasil.

\section{METODE}

Penelitian ini menggunakan pendekatan kualitatif, dengan jenis penelitian studi kasus. Teknik pengumpulan data yang digunakan pada penelitian ini adalah wawancara secara mendalam, observasi lapangan, dan dokumentasi. Analisis yang dilakukan dalam penelitian ini bersamaan dengan pengumpulan data saat di lapangan. Dalam analisis data, peneliti mereduksi data yang telah didapatkan di lapangan, lalu memilah setiap data sesuai fokus penelitian dan selanjutnya membuat kesimpulan pada masingmasing fokus. Pengecekan keabsahan data pada penelitian ini menggunakan teknik triangulasi (sumber dan metode/teknik), ketekunan pengamatan, serta pengecekan anggota.

\section{HASIL}

Peran Kepala SMA Nasional Malang sebagai pemimpin perubahan dalam peningkatan mutu pendidikan adalah (1) menjadi pemimpin yang visioner, yaitu kepala sekolah harus bisa merangkul guru untuk bersama-sama menentukan visi, misi, arah, langkah, target, dan kebijakan yang ditempuh untuk mencapai target yang telah ditentukan, (2) sebagai penanggungjwab terhadap semua progtam dan kegiatan yang ada di SMA Nasional Malang, (3) sebagai lokomotif di mana kepala sekolah adalah orang pertama yang melaksankan program baru, dengan kata lain kepala sekolah harus memberi contoh ketika ada program baru di SMA Nasional Malang, (4) sebagai motivator yang berada di belakang warga sekolah untuk memberi semangat dan dukungan agar selalu melakukan perubahan, (5) sebagai patner kerja yaitu kepala sekolah bersama-sama dengan warga sekolah menjalankan program-program yang ada di SMA Nasional Malang.

Strategi Kepala SMA Nasional agar perubahan yang dibawanya mengarah pada peningkatan mutu pendidikan yaitu dengan cara (1) hanya menerima peserta didik peringkat 1 sampai 10 dengan nilai tes minimal 7.5 dan menaikkan SPP serta uang gedung, (2) menumbuhkan budaya sekolah, yaitu budaya salim, doa bersama dan tausiah, (3) mendisiplinkan peserta didik dengan aturan-aturan yang ketat yang tertuang dalam tata tertib sekolah, (4) melakukan rekrutmen guru baru dengan persyaratan Indeks Kumulatif Prestasi (IPK) minimal 3.5 bagi guru lulusan universitas negeri, dan IPK 3.64 bagi guru lulusan universitas swasta, serta melakukan pengembangan pada tenaga pendidik melalui pelatihanpelatihan, (5) mewajibkkan guru membuat skenario pembelajaran dan melaporkan hasil pembelajaran setelah selesai pembelajaran atau ketika evaluasi mingguan pada yang dilakukan setiap hari senin, (6) memberi kebebasan peserta didik untuk mendesain ruang kelasnya masing-masing untuk kenyamanan belajar, (7) mengadakan program bimbingan belajar bagi peserta didik kelas XII untuk perisapan UN dan SBMPTN bagi peserta didik yang memilih untuk melanjutkan pendidikan pada jenjang yang lebih tinggi, dan (8) mendampingi peserta didik menulis lamaran pekerjaan dan merekomendasikan pada instansi-instansi kerja

Peran dan strategi perubahan yang dilakukan kepala sekolah tersebut melahirkan inovasiinovasi baru untuk menjawab permasalah dan kebutuhan sekolah itu sendiri ataupun masyarakat luas. Inovasi yang dibuat oleh Kepala SMA Nasional Malang adalah (1) membuat program manajemen gopek untuk menumbuhkan karakter baik pada peserta didik, dan (2) membuka kelas atlet sebagai wadah bagi peserta didik yang mempunyai bakat di bidang keolahragaan yang tetap diimbangi dengan kemampuan akademik. Inovasi tersebut didasarkan pada analisis keadaan sekolah sebelum terjadinya perubahan. Program manajemen gopek atau yang lebih dikenal oleh warga SMA Nasional Malang sebagai M Gopek memang dibuat untuk menumbuhkan karakter pada diri peserta didik seperti peduli terhdap sosial, karena hasil dari manajemen gopek ini akan digunakan untuk kegiatan bakti sosial di masyarakat dan 
juga untuk membantu peserta didik SMA Nasional Malang yang kurang mampu dengan memberikan uang saku setiap harinya sebesar Rp 5.000. Sedangakan dengan dibukanya kelas atlet, kepala sekolah ingin memberikan kesempatan seluas-luasnya kepada peserta didik yang mempunyai bakat dan minat pada bidang olahraga untuk mengembangkan bakatnya tersebut. Kelas atlet ini masuk dalam program Ilmu Pengetahuan Sosial (IPS). Beban pembelajaran pada kelas atlet memang lebih ringan dibandingkan dengan kelas reguler lainnya. Pada kelas atlet materi yang diajarkan hanya sebatas pada meteri-materi pokok yang berhubungan dengan materi ujian nasional. Setelah melakukan pembelajaran reguler, peserta didik kelas atlet akan melanjutkan dengan latihan-latihan sesuai bidang olahraga yang dipilihnya.

Faktor yang mendorong terjadinya perubahan di SMA Nasional Malang yaitu berasal dari internal dan eksternal sekolah. Faktor internal yaitu berasal dari (1) kepemimpinan kepala sekolah sendiri, (2) dukungan dari yayasan, serta (3) sarana prasarana yang ada. Sedangkan faktor eksternal terjadinya perubahan yaitu dari (1) kebutuhan masyarakat akan pendidikan pada jenjang SMA, (2) peserta didik yang pintar namun terbatas oleh finansial, yang menyebabkan mereka putus sekolah, dan (3) persaingan antar sekolah, terutama melihta keberhasilan lembaga pendidikan swasta yang lain. Sedangkan fakor yang menghambat terjadinya perubahan di SMA Nasional Malang yaitu berasala dari (1) mind set guru yang selalu takut untuk berubah dan mencoba hal baru, karena takut akan kegagalan, (2) kompetensi guru yang sangat rendah, dan (3) image SMA Nasional Malang yang kurang baik di masyarakat.

\section{PEMBAHASAN}

Peran kepala sekolah sebagai pemimpin perubahan yaitu pertama berperan untuk menentukan visi, misi, serta arah dan target yang ingin dicapai sekolah, sekaligus sebagai penanggungjawab atas semua program dan kegiatan yang ada, mengajak. Hal ini sesuai dengan pendapat Andriani (2008) yang menyatakan bahwa peran pemimpin dalam membawa perubahan adalah sebagai kreator, yaitu kepala sekolah bertugas mengembangkan dan menetapkan visi sekolah dan strategi untuk mencapainya. Kepala SMA Nasional Malang juga berperan sebagai lokomotif, yaitu kepala sekolah memberikan contoh kepada warga sekolah terhadap program-progam baru hasil inovasi dan perubahan tersebut. Hasil ini sesuai dengan pendapat Wibowo (dalam Supriyanto, 2009) yang telah menyebutkan beberapa peran pemimpin dalam membawa perubahan kepada organisasinya, salah satunya yaitu kepala sekolah harus dapat memimpin dengan contoh. Pemimpin sebagai contoh yaitu kepala sekolah harus menjadi model peran bagi orang yang diberdayakan. Andriani (2008) menyatakan bahwa pemimpin dalam membawa perubahan harus berperan sebagai fasilitator, yaitu kepala sekolah bertugas memberikan dukungan terhadap ide-ide atau inisiasi perubahan yang selaras dengan visi perubahan yang telah ditetapkan. Kepala SMA Nasional Malang dalam membawa perubahan juga berperan sebagai motivator yang bertugas mendorong warganya untuk terus melakukan inovasi-inovasi dan menemukan ide-ide baru untuk pengembangan sekolah sehingga dapat terjadi peningkatan mutu.

Strategi Kepala SMA Nasional Malang dalam melakukan perubahan untuk meningkatkan mutu pendidikan yaitu salah satunya dengan memperbaiki manajemen peserta didik di SMA Nasional Malang. Imron (2012) menjelaskan bahwa sistem seleksi pada penerimaan peserta didik baru dapat digolongkan menjadi tiga macam, yaitu seleksi berdasarkan Daftar Nilai Ebta Murni (DANEM), berdasarkan Penelusuran Minat dan Kemampuan (PMDK), dan seleksi berdasarkan hasil tes masuk. Pada sistem seleksi ini, sekolah terlebih dahulu menentukan kriteria atau persyaratan yang harus dipenuhi oleh calon peserta didik baru agar bisa diterima pada lemaga pendidikan tersebut. Kepala SMA Nasional Malang memperbaiki manajemen peserta didik melalui kebijakan yang dibuat pada penerimaan peserta didik baru dengan menggunakan sistem seleksi yaitu hanya menerima peserta didik peringkat 1 sampai 10 dengan nilai tes minimal 7.5. Hal ini dilakukan untuk meningkatkan kualitas input SMA Nasional Malang. Kepala sekolah juga memperbaikki manajemen peserta didik di SMA Nasional Malang dengan memperketat kedisiplinan peserta didik. Menurut Imron (2012) terdapat tiga teknik pembinaan disiplin yang dapat diterapkan yaitu eksternal kontrol, internal kontrol, dan kooperatif kontrol. SMA Nasional Malang menerapkan teknik eksternal contol untuk mendisiplinkan peserta didiknya. Kepala sekolah juga memperbaikki manajemen sumber daya manusia dengan melakukan rekrutmen guru baru yang 
memenuhi persyaratan. Sesuai dengan pendapat Mulyasa (2012:64) "untuk mendapatkan guru dan staf yang sesuai dengan kebutuhan, dilakukan kegiatan rekruitmen, yaitu usaha mencari dan mendapatkan calon-calon guru dan staf yang memenuhi syarat sebanyak mungkin untuk kemudian dipilih calon terbaik dan tercakap". Kepala SMA Nasional juga melakukan supervisi akademik sebagai salah satu strategi perubahan untuk peningkatan mutu pendidikan. Supervisi akademik adalah bantuan profesional kepada guru melalui siklus perencanaan yang sistematis, pengamatan yang cermat, dan umpan balik yang objektif dan segera, yang bertujuan untuk meningkatkan kemampuan professional guru dan meningkatkan kualitas pembelajran (Mulyasa, 2012). Supervisi yang dilakukan oleh Kepala SMA Nasional Malang yaitu dengan mewajibkan guru membuat skenario pembelajaran setiap hari. Dari skenario pembelajaran tersebut kepala sekolah akan melakukan pengecekan dan memberi masukan terhadap pembelajaran skenario yang dibuat oleh guru.

Inovasi yang dibuat oleh Kepala SMA Nasional Malang yaitu program manajemen gopek dan juga kelas atlet. Roger (dalam Suharsaputra, 2016) menyebutkan beberapa karakteristik inovasi, yaitu (1) relative advantage, seseorang akan lebih dapat menerima inovasi jika melihat bahwa hal tersebut akan memberikan manfaat yang lebih besar dari apa yang diperoleh atau dicapai dengan sebelumnya, warga SMA Nasional Malang menerima inovasi yang dibuat oleh kepala sekolah, karena inovasi tersebut dinilai sangat bermanfaat, program manajemen gopek yang dibuat bermanfaat bagi warga sekolah untuk membentuk karakter terutama pada peserta didik, selain pada warga sekolah sendiri, inovasi tersebut bermanfaat bagi masyarakat di sekitar sekolah, karena program manajemen gopek juga digunakan untuk bakti sosial, sedangkan inovasi yang dibuat dengan membuka kelas atlet bermanfaat untuk meningkatkan prestasi non akademik di SMA Nasional Malang, (2) compatibility, menunjukkan tingkat kesesuaian antara inovasi dengan kondisi dan harapan masyarakat (organisasi). Program inovasi yang dibuat oleh Kepala SMA Nasional Malang sesuai dengan keadaan sekolah yang menginginkan perserta didiknya memiliki karakter yang baik dan ingin mencetak atlet yang berpendidikan. Masyarakat juga yang mengharapkan pendidikan bermutu bagi anaknya. Kedua inovasi tersebut dibuat berdasarkan dengan kebutuhan, sehingga inovasi yang dibuat dapat menjawab kebutuhan masyarakat.

Faktor pendukung kepemimpinan perubahan kepala sekolah dalam peningkatan mutu pendidikan di SMA Nasional Malang dari internal yaitu kepemimpinan kepala sekolah yang terus mendorong warganya untuk berubah dan membuat inovasi-inovasi baru, dukungan dari yayasan, dan sarana prasarana sekolah. Hasil tersebut sesuai dengan pendapat Andreson (dalam Wibowo, 2012:93) yang menyatakan faktor penggerak yang dapat memengaruhi terjadinya perubahan salah satunya yaitu pola pikir dari pimpinan. Pola pikir tersebut meliputi pandangan, asumsi, keyakinan atau mental model yang menyebabkan orang berperilaku dan bertindak seperti yang diinginkan. Sedangkan faktor pendukung perubahan di SMA Nasional dari eksternal yaitu banyak orangtua yang menginginkan anaknya dapat bersekolah pada jenjang yang SMA namun tidak sedikit pula dari mereka yang terhalang oleh biaya, dan lembaga pendidikan lain terutama sekolah swasta yang bermutu dan mampu tetap eksis dan diminati masyarakat. Sesuai dengan pendapat Robbins (dalam Wibowo 2012:91) yang menyatakan bahwa "faktor yang memengaruhi organisasi untuk berubah yaitu adanya persaingan dengan organisasiorganisasi lainnya". Untuk dapat tetap bertahan di tengah-tengah persaingan antar sekolah yang semakin tinggi, SMA Nasional harus mampu mempertahankan esksistensinya dengan melakukan perubahan dan inovasi-inovasi baru.

Robbins (2006), menyebutkan beberapa penolakan perubahan yang bersifat individu, yaitu (1) kebiasaan, ada sebagian individu menolak perubahan karena sudah terbiasa dengan "gaya lama" yang ia jalankan. Mereka akan merasa terancam, tersisihkan jika ternyata perubahan yang dilakukan harus meninggalkan kebiasaan-kebiasaannya itu. Hal tersebut dialami oleh guru-guru SMA Nasional Malang. Pada saat itu peta konsep yang dimiliki oleh guru-guru adalah bagaimana cara tetap bisa bekerja tanpa memperdulikan kualitas pendidikan. Pemikiran seperti itu telah tertanam bertahun-tahun yang menjadikan guru-guru nyaman dengan kualitas pendidikan yang rendah. Oleh karena itu, ketika terjadinya perubahan guru-guru merasa tertekan dan menolak program-program perubahan karena mereka takut menemui kegagalan dan yang akan menyebabkan mereka nantinya kehilangan pekerjaan, (2) keamanan, orang dengan kebutuhan yang tinggi akan keamanan cenderung menolak perubahan 
karena akan mengancam perasaan aman mereka. Kompetensi guru SMA Nasional Malang memang dapat dikatakan sangat rendah pada saat itu. Hal ini menjadi salah satu penghambat untuk melakukan perubahan karena kepala sekolah ingin menjadikan lembaga pendidikannya bermutu salah satunya yaitu melakukan rekrutmen peserta didik baru dengan persyaratan yang tinggi. Untuk mengimbangi input yang berkualitas, maka gurunya juga harus berkualitas, karena tidak dapat dipungkiri salah satu faktor keberhasilan peningkatan mutu adalah kegiatan pembelajaran di kelas. Oleh karena itu kompetensi yang rendah ini dirasakan oleh kepala sekolah sebagai salah satu faktor yang menghambat perubahan dalam rangka peningkatan mutu sekolah, (3) faktor-faktor ekonomi, sumber penolakn ini adalah kekhawatiran bahwa perubahan itu akan mengurangi penghasilan seseorang. Dengan adanya perubahan yang dilakukan oleh kepala sekolah, guru-guru SMA Nasional Malang banyak yang menolak disebabkan takut akan terjadinya kegagalan dalam perubahan, yang menjadikan sekolah semakin tidak diminati peserta didik, tentu saja akan berdampak pada penghasilan guru-guru juga.

\section{KESIMPULAN}

Keberhasilan perubahan yang dibawa oleh Kepala SMA Nasional Malang yaitu melalui perannya sebagai filosofis, penanggung jawab, lokomotif, motivator, dan patner kerja. Strategi yang digunakan untuk mewujudkan perubahan tersebut adalah hanya menerima peserta didik peringkat 1 sampai 10 dengan nilai tes minimal 7.5, menumbuhkan budaya sekolah, mendisiplinkan peserta didik dengan memperketat aturan sekolah, melakukan rekrutmen guru baru dan pengembangan melalui pelatihanpelatihan, mewajibkan guru membuat skenario pembelajaran, membebaskan peserta didik mendesain kelas untuk kenyamanan pembelajaran, mengadakan program bimbingan belajar bagi peserta didik kelas XII untuk persipan UN dan SBMPTN, mendampingi peserta didik menulis lamaran pekerjaan dan merekomendasikan pada instansi-instansi kerja. Inovasi yang dibuat yaitu manajemen gopek dan kelas atlet. Faktor pendukung perubahan berasal dari internal sekolah (kepemimpinan kepala sekolah, dukungan yayasan, dan sarana prasarana), dan eksternal sekolah (kebutuhan masyarakat akan pendidikan, dan persaingan antar sekolah). Sedangkan faktor penghambat perubahan yaitu berasal dari mind set guru yag sulit diubah, kompetensi guru yang rendah, dan image SMA Nasional kurang baik di masyarakat.

\section{DAFTAR RUJUKAN}

Andriani, D. 2008. Peran Kepala Sekolah Dalam Upaya Mewujudkan Perubahan Sekolah. (Online), (http://media. neliti.com/media/publications/114328-ID-peran-kepala-sekolah-dalam-upaya-mewujud.pdf), diakses pada 24 Juni 2018.

Imron, A. 2012. Manajemen Peserta Didik Berbasis Sekolah. Jakarta: Bumi Aksara.

Kaufman, H. 1985. Limits Of Organization Change. Alabama: University of Alabama Press.

Mulyasa. 2012. Manajemen dan Kepemimpinan Kepala Sekolah. Jakarta: PT Bumi Aksara.

Mutohar, P. M. 2013. Manajemen Mutu Sekolah: Strategi Peningkatan Mutu dan Daya Saing Lembaga Pendidikan Islam. Yogyakarta: Ar-Ruzz Media.

Robbins, S. 2006. Perilaku Organisasi. Edisi Bahasa Indonesia. Jakarta: PT. Kelompok Gramedia.

Sobri, A. Y. 2016. Kepemimpinan Kepala Sekolah dalam Meningkatkan Kualitas Sekolah dalam Era Masyarakat Ekonomi ASEAN. (Online), (http://ap.fip.um.ac.id/wp-content/uploads/2016/10/Artikel-KS-MEA-AYSobri.pdf), diakses pada 15 Juli 2018.

Suharsaputra, U. 2016. Kepemimpinan Inovasi Pendidikan (Mengembangkan Spirit Entrepreneurship Menuju Learning School). Bandung: PT Refika Aditama.

Wibowo. 2012. Manajemen Perubahan. Edisi Ketiga. Jakarta: Rajawali Pers. 